Research article

\title{
EFFECTS OF ACUTE ADMINISTRATION OF D,L-HOMOCYSTEINE THIOLACTONE ON THE ANTIOXIDATIVE STATUS OF RAT INTESTINE AND LIVER
}

\author{
STOJANOVIĆ Marija ${ }^{1 *}$, ŠĆEPANOVIĆ Ljiljana ${ }^{1}$, BOSNIĆ Olivera ${ }^{1}$, MITROVIĆ \\ Dušan ${ }^{1}$, JOZANOV-STANKOV Olga ${ }^{2}$, ŠĆEPANOVIĆ Vuk ${ }^{3}$, ŠĆEPANOVIĆ \\ Radomir ${ }^{4}$, STOJANOVIĆ Teja ${ }^{5}$, ILIĆ Slobodan ${ }^{6}$, DJURIĆ Dragan ${ }^{1}$
}

\begin{abstract}
${ }^{1}$ Institute of Medical Physiology „Richard Burian“, Faculty of Medicine, University of Belgrade, Belgrade, Serbia; ${ }^{2}$ Institute of Nuclear Sciences Vinca, Laboratory for Radiobiology and Molecular Genetics, University of Belgrade, Belgrade, Serbia; ${ }^{3}$ Institute for Neurosurgery, Clinical Center of Serbia, University of Belgrade, Belgrade, Serbia; ${ }^{4}$ Belgrade University of Defense, Military Medical Academy, Belgrade, Serbia; ${ }^{5}$ Institute of Neonatology, Belgrade, Serbia; ${ }^{6}$ University Children's Hospital, University of Belgrade, Belgrade, Serbia
\end{abstract}

(Received 01 March; Accepted 29 June 2015)

Oxidative stress appears to play a role in the pathogenesis of several inflammatory gastrointestinal diseases. Increased homocysteine levels may play a role in the pathogenesis of Chron's disease and ulcerative colitis. The aim of this study was to examine the influence of homocysteine on the antioxidant status of rat intestine and liver. The levels of thiobarbituric acid reactive substances (TBARS), activity of catalase (CAT) and total antioxidant status (TAS) were investigated in the isolated gut and liver of young male rats in the control group (8 rats) and after 3-hour incubation in high doses of D, L-homocysteine thionolactone (Hcy) $(10 \mu \mathrm{mol} / \mathrm{L})(8 \mathrm{rats})$. Samples of duodenum, ileum, colon and liver were homogenized in sodium phosphate buffer (1:10). Homogenates were centrifuged at 10000 for $10 \mathrm{~min}$ at $4^{\circ} \mathrm{C}$ and the supernatant was taken for biochemical assays. Our results showed that high D, L-homocysteine thionolactone concentration reduced enzymatic catalase activity in homogenates of the isolated segments of duodenum $(27.04 \%) \mathrm{p}<0.01$; ileum $(37.27 \%)$, colon $(34.17 \%)$ and liver $(67.46 \%) \quad \mathrm{p}<0.001$. Exposition to high D,L-homocysteine thiolactone concentration significantly increased TBARS levels in the duodenum $(106.05 \%)$, ileum $(47.24 \%)$, colon $(112.75 \%)$ and liver $(32.07 \%)(p<0.01)$. Homocysteine also modified the total antioxidant status of homogenates from the duodenum, ileum, colon and liver, increasing by $20.68 \%$ (duodenum), $24.74 \%$ (ileum), $14.88 \%$ (colon) and $19.35 \%$ (liver) $(\mathrm{p}<0.001)$. Homocysteine induced a consistent oxidative stress in rat's intestine and liver (reduced activity of catalase and increased level of TBARS), but the elevated activity of TAS in our experiments could be explained as an adaptive response to the generated free radicals which indicates the failure of the total antioxidant defense mechanism to protect the tissues from damage caused by homocysteine.

Key words: antioxidant enzymes, homocysteine, lipid peroxidation, oxidative stress

\footnotetext{
*Corresponding author: e-mail: mrj.stojanovic@gmail.com
} 


\section{INTRODUCTION}

Oxidative stress due to the production of intracellular and extracellular reactive oxygen species may be a major player in the pathogenesis of cardiovascular and other diseases. It is now well established that hyperhomocysteinemia is an independent risk factor for coronary artery diseases, cerebrovascular diseases, and peripheral vascular occlusive diseases. Tissue accumulation of homocysteine (Hcy) occurs in homocystinuria, a metabolic disease characterized by deficiency of cystathionine b-synthase and by mental retardation, vascular problems, skeletal abnormalities, and hepatic compromise, with fatty accumulation and cirrhosis [1].

Oxidative stress appears to play a role in the pathogenesis of several inflammatory gastrointestinal diseases [2,3]. Changes in intestinal motility have been reported in different models of intestinal inflammation. The initiating factor of altered motility could be an alteration of gut redox status. Increased homocysteine levels in the colonic mucosa and plasma of patients with inflammatory bowel disease (IBD) may play a role in the pathogenesis of Chron's disease and ulcerative colitis. Homocysteine is also known to aggravate the pathogenesis of IBD. Interestingly, the colon is the pivot site that regulates Hcy levels in the plasma.

Milton et al. [4] showed that homocysteine inhibited hydrogen peroxide breakdown by catalase (CAT) in the human neuroblastoma cell line. Matte et al. [5] showed that homocysteine induced oxidative stress in rat liver. Streck et al. [6] demonstrated that homocysteine significantly increased thiobarbituric acid-reactive substances (TBARS), but did not change antioxidant enzymes. Their results suggest that oxidative stress is involved in the neurological dysfunction of homocystinuria in the rat hippocampus.

Catalase, an antioxidant enzyme responsible for the degradation of hydrogen peroxide, is protective in many diseases. The amino-acid homocysteine has been suggested to be a pro-oxidant with elevated levels linked to the oxidative stress seen in Alzheimer's and other diseases. This study shows that homocysteine inhibits the breakdown of hydrogen peroxide [7].

The aim of this study was to examine the influence of high level of homocysteine on the antioxidant status of rat intestine tissue (duodenum, ileum, colon) and liver. In the present study, the effects of acute administration of homocysteine thionolactone (metabolite of homocysteine) on the formation of TBARS, total antioxidant status (TAS) and CAT activity were investigated.

\section{MATERIAL AND METHODS}

Wistar rats were obtained from the Central Animal House Department of the Institute of Physiology, University of Belgrade. Animals were treated according to the Guide for the Care and Use of Small Laboratory Animals, School of Medicine, University of Belgrade, License number 5287/2. 
The investigation conforms to the regulations of the European Union and USA Guide for Care and Use of Laboratory Animals published by the US National Institutes of Health, NiH publication No. 85-23, revised 1985.

All chemicals were obtained from Sigma Chemical Co., St. Louis, MO, USA. Rats, aged 20-21 weeks and weighing 160 $200 \mathrm{~g}$ were anesthetized with ketamine $4 \mathrm{mg} / \mathrm{kg}$ body mass. After cervical dislocation the gastrointestinal tract and liver were quickly removed and processed as follows. Group I (control, $\mathrm{n}=8$ ) (duodenum, ileum, colon) and liver were kept in Tyrode's solution, group II (experimental, $n=8$ ) were in Tyrode's solution with homocysteine $(10 \mu \mathrm{mol} / \mathrm{L})$. Both groups were incubated for three hours. After completion of the treatment period, the tissues were homogenized in $10 \mathrm{ml}$ (1:10) of $50 \mathrm{mM}$ sodium phosphate buffer, $\mathrm{pH}$ 7.0. Homogenates were centrifuged at 13000 for $10 \mathrm{~min}$. at $4^{0} \mathrm{C}$ to discard nuclei and cell debris. The supernatant was taken for biochemical assays. The homogenates used were from individual animals and they were not pooled.

Protein contents were measured according to the method of Bratford [8] using bovine serum albumin as standard.

\section{Catalase assay}

Catalase (Cat) activity was determined based on the spectrophotometric measurement according to Aebi [9]. This method was based on the disappearance of $\mathrm{H}_{2} \mathrm{O}_{2}$ at $240 \mathrm{~nm}$ in the reaction medium containing $30 \mathrm{mM} \mathrm{H}_{2} \mathrm{O}_{2}, 50 \mathrm{mmol} / \mathrm{L}$ potassium phosphate buffer $\mathrm{pH} 7.0$ and $0.1 \mathrm{ml}$ sample Cat activity expressed as micromoles of hydrogen peroxide decomposed $/ \mathrm{min} / \mathrm{mg}$ protein.

\section{Lipid peroxidation}

Lipid peroxidation (LPO) was measured in tissue homogenates according to the method of Ohkawa et al. [10]. Briefly, $25 \mu$ l homogenates, $975 \mu$ l TRIS buffer $\mathrm{pH} 7.0$ and $2 \mathrm{ml}$ TBA reagent were added into glass tubes. The mixture was vortexed and reaction was carried out in a boiling water bath for $1 \mathrm{~h}$. The mixture was allowed to cool in water for $5 \mathrm{~min}$. and was centrifuged at $750 \mathrm{x}$ for $10 \mathrm{~min}$ at $25^{\circ} \mathrm{C}$. The obtained resulting pink stained TBARS were determined at $535 \mathrm{~nm}$ (ULTROSPECT 2000, Pharmacia biotech). The measurement was based on the formation of thiobarbituric acid-reactive substances (TBARS) and expressed as the extent of MDA production. TBARS were calculated as $\mu \mathrm{mol}$ TBARS /mg protein.

\section{Tissue total antioxidant status (TAS)}

TAS was measured on Ultrospect 2000 Analyzer with Randox reagent set (Randox). The determination was based on the reaction of 2,2-azino-di-(3-ethylbenythiazoline sulfonate) $\left(\mathrm{ABTS}^{+}\right.$) with peroxidase (metmyoglobin) and $\mathrm{H}_{2} \mathrm{O}_{2}$ to produce the radical cation $\mathrm{ABTS}^{+}$[11]. For the total antioxidant assay, 2,2-azinobis-(3-ethyl- 
benzothiazoline-6-sulfonic acid) (Sigma-Aldrich) was dissolved in deionized water to a $7 \mathrm{mM}$ concentration.

The ABTS radical cation $\left(\mathrm{ABTS}^{+}\right)$was produced by reacting the ABTS stock solution with $2.45 \mathrm{mM}$ potassium persulfate (final concentration) and incubating the solution in the dark at room temperature for 12-16 h before use. The radical stock solution was diluted with a $5 \mathrm{mM}$ solution of phosphate-buffered saline (PBS; $\mathrm{pH} 7.4$ ) to obtain a spectrophotometric absorbance value of $0.700 \pm 0.020$ at $734 \mathrm{~nm}$. Trolox (a Vitamin E analogue) standards (Calbiochem) were prepared in PBS over the range $0-15 \mu \mathrm{M}$. For the standardization of the starting point of all assays and standards, a $10 \mu \mathrm{l} \mathrm{sample} /$ Trolox standard was added to $1 \mathrm{ml} \mathrm{ABTS} \pm$ solution $\left(\mathrm{A}_{734} \mathrm{~nm}=0.700 \pm\right.$ $0.020)$ and an absorbance reading taken exactly 1 min after initial mixing until the decrease in absorbance ceased. Assays were performed in triplicate and validations were performed against PBS to confirm that extraction buffer components did not interfere with the analysis.

The antioxidant activity was expressed as the rate of decrease in absorbance $(\mathrm{min} / \mathrm{mg}$ protein) and as the mean of three replicate samples.

\section{Statistical analysis}

Results were analyzed by standard statistical methods, expressed as mean $\pm \mathrm{SD}$ and graphically presented (Statistical program GraphPad Prism 6). Significance of the differences between the experimental and control groups was determined by Student's t-test. Differences were considered significant at $\mathrm{p}<0.05$.

\section{RESULTS}

\section{Catalase activity, TBARS and TAS in isolated segments of duodenum, ileum, colon and liver incubated in Tyrode"s solution during 3 hours}

The summary of the main characteristics of control values of oxidative stress parameters (catalase activity, TBARS and TAS concentration) are presented in Table I.

Catalase activity showed the highest value in the liver ( $347.63 \pm 60.11 \mathrm{U} / \mathrm{mg}$ protein), the lowest value in the duodenum $(166.50 \pm 10.44 \mathrm{U} / \mathrm{mg}$ protein). There was a statistically significant difference between values in liver and other organs of gastrointestinal tract. Also the differences were found between other organs: duodenum $-\mathrm{D}$; ileum $-\mathrm{I}$, colon $-\mathrm{C}$ were significant $(\mathrm{D} / \mathrm{I} \mathrm{p}<0.01 ; \mathrm{D} / \mathrm{C} \mathrm{p}<0.01 ; \mathrm{D} / \mathrm{L} \mathrm{p}<0.05 ; \mathrm{I} / \mathrm{C}$ not significant ; I/L $\mathrm{p}<0.01, \mathrm{C} / \mathrm{L} \mathrm{p}<0.05)$.

TBARS concentration was the highest in the liver $(2.43 \pm 0.1 \mu \mathrm{mol} / \mathrm{mg}$ protein), the lowest in duodenum $(0.92 \pm 0.23 \mu \mathrm{mol} / \mathrm{mg}$ protein $)$. There was a statistically significant difference between control values in the liver and other examined organs $((\mathrm{P}<0.001)$, but the difference between the duodenum, ileum and colon were not significant (D/I 
not significant; D/C not significant; D/L p <0,001; I/C not significant; I/L p $<0,001$, $\mathrm{C} / \mathrm{L} \mathrm{p}<0,001)$.

TAS values were the highest the duodenum $(7.24 \pm 0.45$ ( $\mathrm{mmol}$ Trolox $/ \mathrm{mg}$ protein), statistically significantly higher compared to the ileum, colon and liver. D/I $\mathrm{p}<0.05$; $\mathrm{D} / \mathrm{C} \mathrm{p}<0.05 ; \mathrm{D} / \mathrm{L} \mathrm{p}<0.05$. There were no significant differences between the values in the other three organs (I/C not significant; I/L not significant, $\mathrm{C} / \mathrm{L}$ not significant).

Table 1. Oxidative stress parameters in the duodenum, ileum, colon and liver of control rats (group I) and rats treated with D,L homocysteine thiolactone (group II)

\begin{tabular}{|c|c|c|c|c|c|c|}
\hline & \multicolumn{2}{|c|}{$\begin{array}{c}\text { Catalase } \\
\text { (U/mg protein) }\end{array}$} & \multicolumn{2}{|c|}{$\begin{array}{c}\text { TBARS } \\
(\mu \mathrm{mol} / \mathrm{mg} \text { protein })\end{array}$} & \multicolumn{2}{|c|}{$\begin{array}{c}\text { TAS } \\
\begin{array}{c}\text { (mmol Trolox } / \mathrm{mg} \\
\text { protein) }\end{array} \\
\end{array}$} \\
\hline & Group I & Group II & Group I & Group II & Group I & Group II \\
\hline Duodenum & $166.50 \pm 10.44$ & $\begin{array}{c}121.45 \pm 4.88^{* *} \\
\downarrow 27.04 \%\end{array}$ & $0.92 \pm 0.23$ & $\begin{array}{c}2.23 \pm 0.28 * * \\
\uparrow 106.05 \% \\
\end{array}$ & $7.24 \pm 0.45^{*}$ & $\begin{array}{c}8.73 \pm 0.64 * * * \\
\uparrow 20.68 \% \\
\end{array}$ \\
\hline Ileum & $291.99 \pm 14.92$ & $\begin{array}{c}203.50 \pm 31.12 * * * \\
\downarrow 37.27 \%\end{array}$ & $1.098 \pm 0.10$ & $\begin{array}{c}1.62 \pm 0.10^{* *} \\
\uparrow 47.24 \%\end{array}$ & $5.39 \pm 0.28$ & $\begin{array}{c}6.73 \pm 0.20 * * * \\
\uparrow 24.74 \%\end{array}$ \\
\hline Colon & $232.11 \pm 14.92$ & $\begin{array}{c}152.79 \pm 15.11 \text { *** } \\
\downarrow 34.17 \% \\
\end{array}$ & $1.10 \pm 0.14$ & $\begin{array}{c}2.34 \pm 0.24 * * \\
\uparrow 112.75 \% \\
\end{array}$ & $5.87 \pm 0.14$ & $\begin{array}{c}6.74 \pm 0.09 * * * \\
\uparrow 14.88 \%\end{array}$ \\
\hline Liver & $347.63 \pm 60.11 *$ & $\begin{array}{c}113.13 \pm 10.77 * * * \\
\downarrow 67.46 \%\end{array}$ & $2.43 \pm 0.18^{* * *}$ & $\begin{array}{c}3.21 \pm 0.29 * * \\
\uparrow 32.07 \%\end{array}$ & $5.34 \pm 0.41$ & $\begin{array}{c}6.27 \pm 0.42 * * * \\
\uparrow 19.35 \%\end{array}$ \\
\hline
\end{tabular}

Data are presented as mean $\pm \mathrm{SE} ; \mathrm{n}=8$ (in the group II \% of changes compared to control value; $\left.{ }^{*} \mathrm{p}<0.05,{ }^{*} \mathrm{p}<0.01,{ }^{* * *} \mathrm{p}<0.001\right)$.

\section{Catalase activity, TBARS and TAS in isolated segments of duodenum, ileum, colon and liver incubated in homocysteine $(10 \mu \mathrm{mol} / \mathrm{L})$ during 3 hours}

Incubation in D,L- homocysteine thionolactone during 3 hours showed a significant influence on antioxidant defenses and lipid peroxidation in all examined organs Table I.

CAT activity was reduced in all investigated organs, maximum decrease was observed in the ileum and liver. In absolute values the highest activity of catalase was observed in the ileum $(203,502 \mathrm{U} / \mathrm{mg}$ protein) and the lowest in the liver $(113.13 \mathrm{U} / \mathrm{mg}$ protein). In Fig. 1 are presented control values and the reduction of catalase activity after incubation in D,L homocysteine thionolactone (it varied from $27.04 \%$ in duodenum to $67.6 \%$ in liver). All the values were significantly different compared to the control group $\mathrm{p}<0.01$, but the differences between the organs were significant too: $(\mathrm{D} / \mathrm{I}$ $\mathrm{p}<0,05 ; \mathrm{D} / \mathrm{C}$ not significant; D/L not significant; I/C not significant; I/L $\mathrm{p}<0,05$, $\mathrm{C} / \mathrm{L}$ not significant).

In Fig F.2 are presented the levels of TBARS. The highest level of TBARS was observed in the liver $(3.21 \mu \mathrm{mol} / \mathrm{mg}$ protein, while in the ileum was the lowest $(1.62 \mu \mathrm{mol} /$ $\mathrm{mg}$ protein). Highest increase compared to the control group was observed in colon $(112.76 \%)$, the lowest in liver $(32.07 \%)$. All the values were significantly different 
compared to control group (D/I not significant; D/C not significant; D/L $\mathrm{p}<0.05$; $\mathrm{I} / \mathrm{C} \mathrm{p}<0.05 ; \mathrm{I} / \mathrm{L} \mathrm{p}<0.001 ; \mathrm{C} / \mathrm{L} \mathrm{p}<0.05)$.

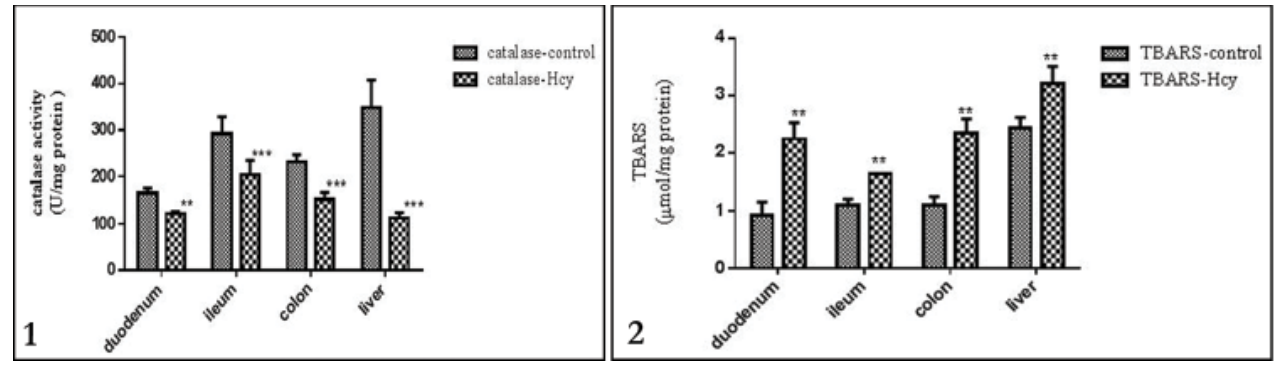

Figure 1. Catalase activity in the duodenum, ileum, colon and liver of control rats (group I) and rats treated with D,L-homocysteine thiolactone (group II) . Results are expressed as mean \pm SD for 8 animals in each group. Different from the controls, ${ }^{* *} \mathrm{p}<0.01 ;{ }^{* *} \mathrm{p}<0.001$ (Student's t-test). Hcy (homocysteine)

Figure 2. TBARS concentration in the duodenum, ileum, colon and liver of control rats (group I) and rats treated with D,L-homocysteine thiolactone (group II) . Results are expressed as mean \pm SD for 8 animals in each group. Different from the controls, ${ }^{* *} \mathrm{p}<0.01$ (Student's t-test). Hcy (homocysteine)

In Fig.3 are presented the levels of TAS. Increased levels varied with highest level observed in duodenum $(8.73 \pm 0.64 \mathrm{mmol}$ Trolox $/ \mathrm{mg}$ protein, the lowest in the liver (6.27 mmol Trolox $/ \mathrm{mg}$ protein). The increase varied from $14.88 \%$ in the colon to $24.74 \%$ in the ileum. All the values are significantly different compared to the control group (D/I p <0.05; D/C p <0.05; D/L p <0.05; I/C not significant; I/L not significant, $\mathrm{C} / \mathrm{L}$ not significant).

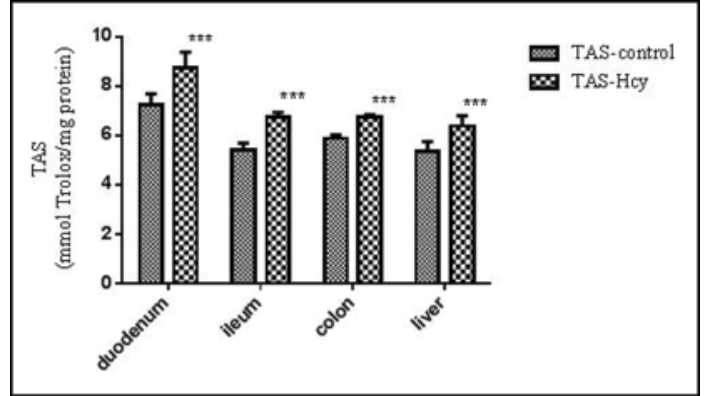

Figure 3. Total antioxidant status in the duodenum, ileum, colon and liver of control rats (group I) and rats treated with D,L-homocysteine thiolactone (group II) . Results are expressed as mean \pm SD for 8 animals in each group. Different from the controls, $* * * p<0.001$ (Student's t-test). Hcy (homocysteine)

\section{DISCUSSION}

In the present study, the effects of acute administration of D,L-homocysteine thiolactone on non-enzymatic and enzymatic antioxidant defenses were investigated in an in vitro animal model of rat duodenum, ileum, colon and liver. 
Incubation of tissues in high D,L-homocysteine thiolactone concentration reduced enzymatic CAT activity in the duodenum, ileum, colon and liver compared to the control group. A significant inhibition of hepatic CAT activity and intestinal CAT activity in rat organs incubated in homocysteine was also verified in literature $[12,13]$. Other studies suggested a negative correlation between plasma Hcy levels and CAT activity in the liver of rats, indicating a significant reduction of hepatic antioxidant defense $[13,14]$. We observed a significant inhibition of hepatic CAT activity in hyperhomocysteinemic rats. In agreement with our data, other studies suggest a negative correlation between plasma Hcy levels and CAT activity in the liver of rats, pointing a significant reduction of hepatic antioxidant defense $[15,16]$. The results from this study show that homocysteine can act directly on catalase and inhibit the breakdown of $\mathrm{H}_{2} \mathrm{O}_{2}$. The suggestion that homocysteine can itself generate $\mathrm{H}_{2} \mathrm{O}_{2}$, with the assistance of copper, has provided a proposed mechanism for this contribution.

Exposition to high D,L-homocysteine thiolactone concentrations significantly increased TBARS levels in the duodenum, ileum, colon and liver. Kolling et al. [17] showed that Hcy increased lipid peroxidation and TBARS level in rats' heart. Lipid peroxidation was also observed in the liver of rats, and was associated with Hcyinduced cell injury, including apoptosis and inflammation in liver disease $[12,13]$. Hepatic lipid peroxidation appears to be strongly associated with Hcy levels [18].

Similar results reported Matte et al. [5]. They showed the occurrence of oxidative stress and notably reduced antioxidant defenses (enzymatic and non-enzymatic) and increased lipid peroxidation, and inflammatory infiltration in the liver of Hcy-treated rats.

TAS is a more useful index of antioxidant status because it considers not only the quantity, but also the reactivity of antioxidants. Our results showed that Hcy increased the total antioxidant status of homogenates from the duodenum, ileum, colon and liver suggesting that this amino acid causes the acute increase of quantity of nonenzymatic antioxidants in the liver and intestine.

The elevated activity of TAS is due to the adaptive response to generated free radicals, indicating the failure of the total antioxidant defense mechanism to protect the tissues from mechanical damage caused by homocysteine, as evidenced by lipid peroxidation.

According to our findings, homocysteine, during exposition, directly inhibited catalase activity, activated the process of lipid peroxidation and elevated total antioxidant status in the isolated intestine and liver. The observed increase in lipid peroxidation and TAS suggests the presence of oxidative stress in the gastrointestinal system.

A correlation between oxidative stress and high levels of homocysteine has been demonstrated in vascular smooth muscle cells [19]. Homocysteine inhibits endothelium-dependent NO-mediated dilation in the porcine retinal arterioles by producing superoxide from $\mathrm{NAD}(\mathrm{P}) \mathrm{H}$ oxidase [20].

Although the present study only concerns the acute effects of Hcy on oxidative stress parameters in rats, it is tempting to consider the reported prooxidant effects of Hcy on the gastrointestinal system in animals and humans. It is proposed that chronic 
oxidative stress contributes to the pathogenesis of some inflammatory digestive diseases. Reactive oxygen species (ROS) are produced within the gastrointestinal (GI) tract, but their roles in the pathophysiology and disease pathogenesis have not been well studied. Elevated levels of plasma homocysteine have been implicated in inflammation and remodeling of the intestinal vasculature, and Hcy is also known to aggravate the pathogenesis of inflammatory bowel disease (IBD), Chron's, disease, ulcerative colitis, etc. Interestingly, the colon is the pivot site that regulates Hcy levels in the plasma. Levels of ROS, superoxide, and inducible nitric oxide were elevated in hyperhomocysteinemia. A large number of literature data indicates that oxidative stress correlates with the level of homocysteine in diseases of the digestive tract [21]. Early identification of hyperhomocysteinemia and markers of oxidative stress may reduce the progression of some gastrointestinal diseases and their complications such as inflammatory bowel disease, Crohn's disease, ulcerative colitis and susceptibility to thrombotic events [21].

Low erythrocyte catalase enzyme activity was found to correlate with high serum total homocysteine levels in Tunisian patients with acute myocardial infarction. Hyperhomocysteinemia may increase the myocardial wall dysfunction by excessive production of reactive oxygen species which is made evident by increased lipid peroxidation [22-24].

During chronic exposition to high levels of homocysteine, the patients with diabetes mellitus, cardiovascular disease and gastrointestinal disease, obesity and metabolic syndrome showed decreased levels of TAS [25].

The significant correlation between oxidative stress markers levels and Hcy levels was found in the study by Nanetti et al [26]. They suggested that Hcy levels control could positively interact with some of the pathological changes involved in the evolution of cerebral ischemic damage. Milton [4] showed that homocysteine inhibited hydrogen peroxide breakdown by catalase in human neuroblastoma cell line.

Oxidative damage is involved in the pathogenesis of primary open angle glaucoma and homocysteine has a role in the development of this type of glaucoma [27]. It has been reported that elevated homocysteine (Hcy) may activate oxidative stress and reduce bone mineral density in post-menopausal osteoporosis [28].

The pathogenesis of various GI diseases including peptic ulcers, gastrointestinal cancers, and inflammatory bowel disease is in part due to oxidative stress [2,3]. Unraveling the signaling events initiated at the cellular level by oxidative free radicals as well as the physiological responses to such stress are important to better understand disease pathogenesis and to develop new therapies.

\section{Acknowledgements}

This work was supported by Grant 175043 from the Ministry of Science and Technology of Serbia. 


\section{Authors' contributions}

LjŠ, MS study conception and design and drafting of manuscript. OB, OJS, VŠ, TS acquisition of data. SI, RS analysis and interpretation of data. DM, DDj critical revision.

\section{Declaration of conflicting interests}

The author(s) declared no potential conflicts of interest with respect to the research, authorship, and/or publication of this article.

\section{REFERENCES}

1. Mudd SH, Skovby F, Levy HL, Pettigrew KD, Wilcken B, Pyeritz RE: The natural history of homocystinuria due to cystathionine beta-synthase deficiency. Am J Hum Genet 1985, 37: $1-31$.

2. Bhattacharyya A, Chattopadhyay R, Mitra R, Crowe SE: Oxidative stress: an essential factor in the pathogenesis of gastrointestinal mucosal diseases. Physiol Rev 2014, 94: 329-354.

3. Hijová E, Szabadosova V, Štofilová J, Salaj R, Bomba A: Inulin diet intervention on chemopreventive and inflammatory markers in tumorigenesis of colorectal cancer. Acta Veterinaria 2014, 64(4): 519-525.

4. Milton NG: Homocysteine inhibits hydrogen peroxide breakdown by catalase. Open Enzym Inhib J 2008, 1: 34-41.

5. Matté C, Stefanello FM, Mackedanz V, Pederzolli CD, Lamers ML, Dutra-Filho CS, Dos Santos MF, Wyse AT: Homocysteine induces oxidative stress, inflammatory infiltration, fibrosis and reduces glycogen/glycoprotein content in liver of rats. Int J Dev Neurosci 2009, 27: 337-344.

6. Streck EL, Vieira PS, Wannmacher CM, Dutra-Filho CS, Wajner M, Wyse AT: In vitro effect of homocysteine on some parameters of oxidative stress in rat hippocampus. Metab Brain Dis 2003, 18: 147-154.

7. Cankurtaran M, Yesil Y, Kuyumcu ME, Oztürk ZA, Yavuz BB, Halil M, Ulger Z, Cankurtaran ES, Arıoğul S: Altered levels of homocysteine and serum natural antioxidants links oxidative damage to Alzheimer's disease. J Alzheimers Dis 2013, 33: 1051-1058.

8. Bradford MM: A rapid and sensitive method for the quantitation of microgram quantities of protein utilizing the principle of protein-dye binding. Anal Biochem 1976, 72: 248-254.

9. Aebi H: Catalase in vitro. Methods Enzymol 1984, 105: 121-126.

10. Ohkawa $\mathrm{H}$, Ohishi N, Yagi K: Assay for lipid peroxides in animal tissues by thiobarbituric acid reaction. Anal Biochemistry 1979, 95: 351-358.

11. Johnstone C, Day JG, Staines H, Benson EE: The development of a 2,2'-azinobis-(3ethyl-benzothiazoline-6-sulfonic acid) radical cation decolourisation assay for evaluating total antioxidant status in an alga used to monitor environmental impacts in urban aquatic habitans. Ecol Indic 2006, 6: 280-289.

12. Huang RF, Hsu YC, Lin HL, Yang FL: Folate depletion and elevated plasma homocysteine promote oxidative stress in rat livers. J Nutr 2001, 131: 33-38. 
13. Woo CW, Prathapasinghe GA, Siow YL: Hyperhomocysteinemia induces liver injury in rat: Protective effect of folic acid supplementation. Biochim Biophys Acta 2006, 1762: 656-665.

14. Chanson A, Rock E, Martin JF, Liotard A, Brachet P: Preferential response of glutathionerelated enzymes to folate-dependent changes in the redox state of rat liver. Eur J Nutr 2007, 46: 204-212.

15. Starkebaum G, Harlan JM: Endothelial cell injury due to coppercatalyzed hydrogen peroxide generation from homocysteine. J Clin Invest 1986, 77: 1370-1376.

16. Gonzalez-Flecha B, Llesuy S, Boveris A: Hydroperoxide-initiated chemiluminescence: an assay for oxidative stress in biopsies of heart, liver and muscle. Free Radic Biol Med 1991, 10: 93-100.

17. Kolling J, Scherer EB, da Cunha AA, da Cunha MJ, Wyse AT: Homocysteine induces oxidative-nitrative stress in heart of rats: prevention by folic acid. Cardiovasc Toxicol 2011, 11: 67-73.

18. Kukolj V: Myofibroblasts in normal and fibrotic liver in different animal species. Acta Veterinaria 2014, 64(4): 397-412.

19. Yan SK, Chang T, Wang H, Wu L, Wang R, Meng QH: Effects of hydrogen sulfide on homocysteine-induced oxidative stress in vascular smooth muscle cells. Biochem Biophys Res Commun 2006, 351: 485-491.

20. Omae I, Nagaoka T, Tanano I, Yoshida A: Homocysteine Inhibition of EndotheliumDependentNitric Oxide-Mediated Dilation of Porcine Retinal Arterioles via Enhanced Superoxide Production. Invest Ophthalmol Vis Sci 2013, 54: 2288-2295.

21. Morgenstern I, Raijmakers MT, Peters WH, Hoensch H, Kirch W: Homocysteine, cysteine, and glutathione in human colonic mucosa: elevated levels of homocysteine in patients with inflammatory bowel disease. Dig Dis Sci 2003, 48: 2083-2090.

22. Góth L, Vitai M: The effects of hydrogen peroxide promoted by homocysteine and inherited catalase deficiency on human hypocatalasemic patients. Free Radic Biol Med 2003, 35: 882-888.

23. Ji C, Kaplowitz N: Hyperhomocysteinemia, endoplasmic reticulum stress, and alcoholic liver injury. World J Gastroenterol 2004, 10: 1699-1708.

24. Noichri Y, Chalghoum A, Chkioua L, Baudin B, Ernez S, Ferchichi S, Miled A: Low erythrocyte catalase enzyme activity is correlated with high serum total homocysteine levels in Tunisian patients with acute myocardial infarction. Diagn Pathol 2013, 30: 8-68.

25. Evelson P, Travacio M, Repetto M, Escobar J, Llesuy SF, Lissi E: Evaluation of total reactive antioxidant potential (TRAP) of tissue homogenates and their cytosols. Arch Biochem Biophys 2001, 388: 261-266.

26. Nanetti T, Vignini A, Raffaelli F, Giulietti F, Bartolini M, Cecilia Perozzi C, Silvestrini M, Provinciali L, Mazzanti L: Homocysteine and oxidative stress in acute stroke. Advances in Bioscience and Biotechnology 2013, 4: 15-23.

27. Atti SH, Saseekala A, VS A: Homocysteine levels and role of oxidative stress in primary open angle glaucoma. IJCRR 2012, 4: 52-58.

28. Zhang Y, He Y, Zong Y, Guo J, Sun L, Ma Y, Dong W, Gui L: 17ß-estradiol attenuates homocysteine-induced oxidative stress and inflammatory response as well as MAPKs cascade via activating PI3-K/Akt signal transduction pathway in Raw 264.7 cells. Acta Biochim Biophys Sin 2015, 47: 65-72. 


\section{EFEKTI AKUTNE ADMINISTRACIJE D,L-HOMOCISTEIN TIOLAKTONA NA ANTIOKSIDATIVNI STATUS CREVA I JETRE PACOVA}

STOJANOVIĆ Marija, ŠĆEPANOVIĆ Ljiljana, BOSNIĆ Olivera, MITROVIĆ Dušan, JOZANOV-STANKOV Olga, ŠĆEPANOVIĆ Vuk, ŠĆEPANOVIĆ Radomir, STOJANOVIĆ Teja, ILIĆ Slobodan, DJURIĆ Dragan

Oksidativni stress igra ulogu u patogenezi brojnih gastrointestinalnih inflamatornih obolenja. Povišen nivo homocisteina može imati ulogu u patogenezi Kronove bolesti i ulceroznog kolitisa. Cilj ovog rada je da ispita uticaj homocisteina na antioksidativni status u tkivu creva i jetre pacova. U crevu i jetri pacova muškog pola praćeni su nivoi reaktivnih supstanci tiobarbiturne kiseline (TBARS), aktivnost katalaze (CAT), i totalni antioksidativni status (TAS) u kontrolnoj grupi (8 pacova) i posle tročasovne inkubacije u D,L-homocistein tiolaktonu $(10 \mu \mathrm{mol} / \mathrm{L})$ (8 pacova). Uzorci tkiva duodenuma, ileuma, kolona i jetre su homogenizovana u fosfatnom puferu (1:10). Homogenati su centrifugirani na 10000 obrtaja $10 \mathrm{~min}$ na $4^{0} \mathrm{C}$ i supernatanti su korišćeni za biohemijske analize. Naši rezultati su pokazali da visoka koncentracija D,L-homocistein tiolaktona smanjuje aktivnost katalaze u homogenatima izolovanih segmenata duodenuma $(27.04 \%) \mathrm{p}<0.01$; ileuma $(37,27 \%)$, kolona $(34,17 \%)$ i jetre $(67,46 \%)$ $\mathrm{p}<0.001$. Izlaganje visokim koncentracijama $\mathrm{D}, \mathrm{L}-$ homocistein tiolaktona značajno povećava nivo TBARS u duodenumu (106.05\%), ileumu (47.24\%), kolonu (112.75\%) i jetri $(32.07 \%)(p<0.01)$. Homocistein takođe modifikuje totalni antioksidativni status u homogenatima duodenuma, ileuma, kolona i jetre, povećavajući ga za $20.68 \%$ (duodenum), 24.74\% (ileum), 14.88\% (kolon) i 19.35\% (jetra) ( $<<0.001)$. Homocistein dovodi do oksidativnog stresa u tkivu creva i jetre pacova (smanjena aktivnost katalaze i povećan nivo TBARS), a povišena aktivnost TAS-a u našem eksperimentu se može objasniti kao adaptivni odgovor na stvaranje slobodnih radikala i pokazuje na neuspeh ukupnog mehanizma antioksidativne odbrane u zaštiti tkiva od oštećenja izazvanih homocisteinom. 